\title{
Wayfinding: Students with Learning Disabilities in Postsecondary
}

\author{
Amy Domenique Gadsden \\ University of Alberta, Canada
}

\begin{abstract}
Students with learning disabilities (SLD) are increasingly present in post-secondary environments in Canada [10]. Current research has examined fragmented components of their lived experiences such as factors that facilitate success or failure at school, personal attributes and characteristics. The existing studies remain somewhat reductive in their scope, failing to address or holistically capture the multi-faceted dimensions of the disability experience, and often framing it in terms of at-risk or deficit models of disability. This paper will provide a brief review of the existing research in this area which reveals both the important contributions of studies to date and new questions and methods that can be explored. The paper will also highlight the author's current research and initial findings that attempt to address these themes more holistically.
\end{abstract}

\section{Introduction}

Existing research has documented the barriers students with disabilities (SLD) face in their education [13] that adversely influence development, impacting overall education and life outcomes [6]. Disparate post-secondary education (PSE) achievement and outcomes persist for SLD compared to their non-disabled peers despite a growth of inclusive policies, pedagogy, and research agendas in the significant yet now dated last federal research study [18]. This gap indicates that SLD continue to face significant challenges and barriers specific to higher education.

Learning disability. Definitions of learning disability (LD) are situated contextually. These include legislative, committee, and medical definitions used to operationalize LD. For the purposes of this paper, the definition developed by the National Committee on Learning Disabilities (1990; 2016) has been selected:

Learning Disabilities refer to a
heterogeneous group of disorders
manifested by significant difficulties in
the acquisition and use of listening,
speaking, reading, writing, reasoning,
or mathematical abilities. These
disorders are intrinsic to the individual,
presumed to be due to central nervous
system dysfunction, and may occur
across the life span. Problems in self-
regulatory behaviors, social
perception, and social interaction may

exist with learning disabilities but do not by themselves constitute a learning disability. Although learning disabilities may occur concomitantly with other conditions (for example, sensory impairment, mental retardation, social and emotional disturbance) or with environmental influences (such as cultural differences, insufficient/inappropriate instruction, psychogenic factors), it is not the result of those conditions or influences.

These difficulties vary in severity, typically persist across the lifespan, and may affect one or more areas of an individual's life, including learning, work, and social and emotional functioning. Students with learning disabilities may share diagnoses and difficulties in academic, socioemotional and psychological domains; however, they are a heterogeneous group comprised of individuals who respond to and make meaning from their experiences in different ways. Such students face significant challenges and barriers specific to higher education; they may, for instance, be unable to advocate for themselves or may be unwilling to disclose their LD to access accommodations that would mitigate the impact of their LD and improve their academic achievement.

\section{Literature Review}

While the barriers facing SLD in elementary and secondary school have been widely studied, there remains a key gap in our understanding of how SLD in post-secondary studies experience, respond to, make meaning and find significance in their schooling experiences.

An in-depth survey of the literature reveals both the important contributions of studies to date and the opportunity for new kinds of methods and questions in accessing the complex experiences of SLD in PSE. Not only are their voices largely absent and underrepresented in the literature, but existing research in this area is primarily quantitative and limited in breadth and depth. The qualitative studies that exist do not address the multi-faceted dimensions of the disability experience and are often framed in atrisk or deficit models of disability.

The author's current research attempts to addresses this gap by exploring the perceptions and experiences of academically high-achieving graduate students 
with learning disabilities to understand how these SLD make meaning of their schooling experiences.

\section{Methodology: Interpretive Case Study}

In response to this, the researcher has developed a more in-depth, sophisticated understanding that extends beyond the normative attributes and perspectives of students to comprehend who they are as a whole - human beings. To address the stated gap, the author conducted an interpretive inquiry (specifically, a qualitative interpretive case study) guided by hermeneutics [10] [3]. The aim is to develop a more in-depth, sophisticated understanding of how these individuals experience and construct their world [4]. A goal of this work is to transform understanding of the participants' experiences through dialectical engagement with participants and through identifying whole-part relationships.

This interpretive approach allowed for a deep insight into the "complex world of lived experience from the point of view of those who live it" [15]. This involved interviewing one male and two female graduate university students who self-identify with LD. A case study for each participant has been developed before studying similarities and differences within and among the three cases.

To develop the case studies, the researcher used the format suggested by Ellis [5]: a) an introduction or narrative portrait that offers a holistic sense of the person; b) an introduction to the site(s) - i.e., the programs, institutions, times and places - in which the students' experiences occurred; c) examples of these experiences; and d) the participants' expressed views about the experiences. The interviews included four clusters of open-ended questions on the following topics to invite other memories and ideas for the participants to share: a) their lives in general; b) their earlier years; c) their earlier school experiences from kindergarten through grade 12; and d) their university experience. In follow-up interviews, the participants were invited to say more about the experiences or ideas mentioned in the initial interview.

The case studies are interpretive in emphasis [10]. This means that the researcher made sense of the data in part by using their preconceptions and preunderstandings, and used their own judgement to evaluate and improve upon the interpretations [4]. This is a rigorous process guided and informed by key ideas and metaphors in hermeneutics including the following: the identification of whole-part relationships to gain a clear understanding of the coconstituted inter-relationship between the individual and their world [12]; heightened attention to language and discourse communities and the political and historical context in which the individuals speak [3]; and, the use of the hermeneutic circle in interpretation to make initial sense of the data in light of one's own interpretive framework, later re-examining the data for gaps, inconsistencies and contradictions. Based on this analysis, the researcher worked to produce a holistic account of each participant's experience in school that offers insights into the complexity of that experience, uncovering richly nuanced data that have never been accessed before.

\section{Preliminary Findings}

The existing qualitative and quantitative research contribute in different and complementary ways to our understanding of variables that influence how SLD experience their education. The quantitative research established discernable relationships between identified variables that affect, for example, the developmental aspects of SLD and their achievement in school. This work has identified key variables and established relationships that affect outcomes. These include developmental aspectsself-concept, self-esteem, self-efficacy-and outcomes such as academic, social, emotional, health, PS participation, and vocation [6]. The qualitative research looks at these established relationships and seeks to address or deepen understanding of the causes, effects, and mechanisms that they suggest such as the relationship between how SLD think and feel about themselves and their established relationship to academic achievement [6].

Interpretive case studies informed by philosophical hermeneutics are complex, in-depth, and deal with theories rather than descriptions of a phenomenon exclusively [6]. In this type of work, the researcher's aim is to develop a more sophisticated understanding and the meaning and significance of experience for participants [4] [7]. The objective of my work is to "understand the nature of setting, what it means for participants to be in that setting, what their lives are like, what's going on for them, what their meanings are, what their world looks like" [10]. This requires an attention to the "whole-part relationships in order to discern the meaning of particular experience" [5]. By focusing attention on meaning making, my interpretive case study research carries this understanding forward, bringing us closer to an indepth, sophisticated understanding of the multifaceted dimensions of the disability experience from the perspectives of SLD.

Preliminary analysis of participant data suggests nuanced understandings of the educational experiences of academically high-achieving SLD in PSE. Table 1. Initial Analysis succinctly highlights how the authors' current work moves the existing research forward. 
Table 1. Initial Analysis

\begin{tabular}{|c|c|c|}
\hline $\begin{array}{l}\text { Established Variables } \\
\text { Quantitative Research }\end{array}$ & $\begin{array}{c}\text { Established Relationships } \\
\text { Qualitative Research }\end{array}$ & $\begin{array}{l}\text { Transformed Understanding } \\
\text { Interpretive Case Study }\end{array}$ \\
\hline $\begin{array}{l}\text { Self-concept and } \\
\text { determination of SLD has } \\
\text { been correlated with } \\
\text { academic achievement[19] }\end{array}$ & $\begin{array}{l}\text { Self-understanding including } \\
\text { orientation of LD critical in decision } \\
\text { making of SLD } \\
\text { Impacts behaviours such as self- } \\
\text { disclosure and self-advocacy } \\
\text { Resultant impacts access to } \\
\text { accommodations and overall academic } \\
\text { achievement [18] }\end{array}$ & $\begin{array}{l}\text { passing v. disclosure, } \\
\text { diagnosis v. labelling, } \\
\text { isolation v. community, } \\
\text { visibility v. invisibility } \\
\text { Safety v. Danger }\end{array}$ \\
\hline $\begin{array}{l}\text { Faculty perceptions of SLD } \\
\text { related to academic } \\
\text { achievement of SLD [17] }\end{array}$ & $\begin{array}{l}\text { Negative educator perceptions of SLD } \\
\text { (e.g., stereotyping) enacted in } \\
\text { gatekeeping behaviours (e.g., refusal } \\
\text { to accommodate and utilize inclusive } \\
\text { pedagogy) [14] }\end{array}$ & $\begin{array}{l}\text { inclusion } \mathrm{v} \text {. exclusion } \\
\text { ability } \mathrm{v} \text {. disability } \\
\text { empowerment } \mathrm{v} \text { disempowerment } \\
\text { limitation } \mathrm{v} \text {. freedom } \\
\text { understanding v. misunderstanding } \\
\text { *Passive Discrimination }\end{array}$ \\
\hline $\begin{array}{l}\text { SLD have higher rates of } \\
\text { depression when compared } \\
\text { to non-learning-disabled } \\
\text { peers [1] }\end{array}$ & $\begin{array}{l}\text { How SLD understand their LD affects } \\
\text { how they feel about themselves and its } \\
\text { impact on their life [5] }\end{array}$ & $\begin{array}{l}\text { labelling } \\
\text { grief } \\
\text { loss } \\
\text { Wacrifice }\end{array}$ \\
\hline
\end{tabular}




\section{Discussion}

The researcher acts as a reflective interpreter in interpretive case study -a key metaphor required for this method. This requires the researcher to move inside, seeking to understand the way of life and meanings of the participants and aiming to see meaning in the "mess" [21].

Safety v. danger. A key aspect of the mess is the negotiation of space for SLD in PSE unique to their sense of safety. These include a navigation of challenges specific to their experiences and meaning making. Participants expressed that others deduced their identity to their diagnosis, which revealed itself to involve stigmatization, negative perceptions, stereotypes and limiting them to another's perception of who they are and what SLD are capable of, leaving them feeling in danger! One participant in particular, Jane, recounted how her peers determined it was acceptable to have accommodations as long as the subsequent achievement does not eclipse that of a person without LD; otherwise it was seen as an unfair advantage! How could she do well and have LD?! She also expresses a sensitivity to how others perceive her disability as something that limits her ability, despite her understanding that it does not. Following her disclosure to peers, she experienced stigmatization: ... They pick on you. And make comments like, 'oh there she goes. She's the kid that goes and gets resource room help...it's not fair'. This sort of misunderstanding by peers continued in postsecondary: 'I'll never forget those people in undergrad, asking 'what are you?'. This type of misunderstanding and stigmatization perpetuated feeling unsafe.

Passive discrimination. These perceptions are then enacted in the behaviours of those in power, which disempowers those with SLD. Participants expressed a strong desire to name their experiences of others behaviours towards them: discrimination. Particularly, passive discrimination, which is stereotyping and gatekeeping, enacted in their world. For these students, disempowerment has been experienced as institutional, environmental and social inequities and barriers such as exclusive pedagogy, misunderstanding, and a lack of accommodations which indicates a $\mathrm{n}$ unwillingness of those in positions of power.

Wounds. Gabor Mate writes that every person has negative experiences. It is the meaning and significance these are given, and being bereft to navigate these alone, that results in trauma. Unhealed trauma, then becomes a wound. In feeling unsafe and discriminated against, participants revealed their meaning-making of experienced trauma, which resulted in woundedness. This highlights the critical role of feelings of safety for participants, which they expressed as a sense of belonging, community, connection, inclusive pedagogy and provision of accommodations.

Wayfinding.The perennial hypervigilant navigation - movement - of a number of tensions such as safety and danger, space and place, understanding of self and orientation of LD, as well as experienced passive discrimination, has resulted in participant woundedness. SLD respond differently to safety, danger, discrimination and wounding. For one participant, woundedness acted as a key motivator in the participants' relentless pursuit of academic excellence, research, teaching and advocacy of SLD. Advocacy through inclusive pedagogy, understanding of learners (e.g., compassion, brain development etc.) through understanding of self and subsequent meaning making, and working to develop a network, a community where SLD can be safe to be their whole selves free from misunderstanding and enacted stereotyping, stigmatization and othering. The instability of traversing often unsafe terrain is a key motivator for the participant. Instead of collapsing from fatigue and exhaustion, the participant has developed key self-understandings which has allowed her to marshall and transform her experiences from a space of grief, fatigue, anger and disappointment to a place of advocacy, hope, community and belonging. Formally understood in existing literature as inclusion, she builds a community and sense of belonging through this pedagogical and philosophical approach of constructivism.

The significance of this research lies in advancing our understanding of high-achieving graduate students with learning disabilities in post-secondary education. Accessing the voices of these students will provide unique insight into the friction between policy, practice, and lived experience. This understanding can inform and enhance decisions regarding practices, pedagogy and policies to enable students with learning disabilities to fully participate in higher education and improve their achievement.

The researcher acknowledges that this work is ongoing and will continue to analyze the individual cases and later, across cases. It will be interesting to examine how participants seek safety in spaces, or, embrace the discomfort of danger and experience growth. Space for this participant became a place when belonging was felt.

\section{Conclusion}

These initial findings highlight the importance of increased, methodologically diverse approaches to understanding the schooling experiences of SLD in PSE. In absence of methodological diversity and inclusion of student voice, research will fail to investigate the complexity of their disability experience, which is critical in understanding the problem holistically. Research must move forward in 
terms of providing a more sophisticated understanding of the phenomenon from those who live it.

The researcher has developed the term passive discrimination to describe an evolving understanding of gatekeeping, specific to my education and equity research projects. It can be understood as the activity of controlling and usually limiting access to something - stigmatization enacted in the world [6].

\section{References}

[1] Alesi, M., Rappo, G., \& Pepi, A. (2014). Depression, anxiety at school and self-esteem in children with learning disabilities. Journal of psychological abnormalities, 1-8.

[2]Chapman,J.W.(1988).Cognitive-motivational characteristics and academic achievement of learning disabled children: A longitudinal study. Journal of Educational Psychology, 80(3), 357-365.

[3] Ellis, J. L. (1998). The teacher as interpretive inquirer. Teaching from understanding: Teacher as inquirer, J. L. Ellis, ed. New York: Garland Publishing, pp. 1-14.

[4] Ellis, J. (2006). Researching children's experiences hermeneutically and holistically. Alberta Journal of Educational Research, 52(3), 111-126.

[5] Ellis, J. (2009). Interpreting results. In A.J. Mills, G. Durepos, \& E. Weibe (Eds.), Encyclopedia of case study research (pp. 484-486). Thousand Oaks, CA: Sage.

[5] Fullarton, S., Duquette, C. (2016). Experiences of students with learning disabilities in Ontario

Universities: A case study. International Journal of Special Education, 31, 55-66.

[6] Gadsden, A.D. (2020). An invitation: Academically high-achieving students with learning disabilities. International Journal of Technology and Inclusive Education (IJTIE), Volume 9, Issue 2, ISSN 2047-0533.

[6] Goldberg, R., Higgins, E., Raskind, M., \& Herman, K. (2003). Predictors of success in individuals with learning disabilities: A qualitative analysis of a 20-year longitudinal study. Learning Disabilities Research and Practice, 18(4), 222-236. http://dx.doi.org/10.1111/1540-5826.00077

[7] Heiman, T., \& Precel, K. (2003). Students with learning disabilities in higher education: Academic strategies profile. Journal of learning disabilities, 36(3), 248-258.

[8] Heyman, W. B. (1990). The self-perception of a learning disability and its relationship to academic self-concept and self-esteem. Journal of Learning Disabilities, 23(8), 472475 .

[9] Lackaye, T., Margalit, M., Ziv, O., \& Ziman, T. (2006). Comparisons of self-efficacy, mood, effort, and hope between students with learning disabilities and their nonLD-matched peers. Learning Disabilities Research \& Practice, 21(2), 111-121.
[10] Merriam, S. (1998). Case studies as qualitative research. In S. B. Merriam, Qualitative research and case study applications in education (pp. 26-43). San Francisco, CA: Jossey-Bass Publishers.

[11] Murray, C., \& Wren, C.T. (2003). Cognitive, academic, and attitudinal predictors of the grade point averages of college students with learning disabilities. Journal of Learning Disabilities, 36, 407-415.

[12] Patterson, M. E., \& Williams, D. R. (2002). Collecting and analyzing qualitative data: Hermeneutic principles, methods, and case examples. Champaign, IL: Sagamore Publishing.

[13] Paul, S. (2000) Students with disabilities in higher education: a review of the literature, College Student Journal, 34, 200-210.

[14] Poed, S., Cologon, K., \& Jackson, R. (2006). Gatekeeping and restrictive practices with students with disability: Results of an Australian survey. Education, 24, $2 b$.

[15] Schwandt, T. A. (2003). Three epistemological stances for qualitative inquiry: Interpretivism, hermeneutics, and social constructionism. In N. K. Denzin \& Y. S. Lincoln (Eds.), The landscape of qualitative research (2 ed., pp. 292-331). Thousand Oaks, CA: Sage Publications.

[16] Skinner, M. E. (1999). Characteristics of "successful" and "unsuccessful" college students with learning disabilities. Paper presented at the annual convention of the Council for Exceptional Children, Charlotte, NC.

[17] Sniateki, J. Perry, H. \& Snell, L. (2015). Faulty attitudes and knowledge regarding college students with disabilities. Journal of Postseondary Education and Disability.

[18] Statistics Canada. (2012). Canadian survey on disability 2012: Tables (Part II). Catalogue no.89-628-X no. 014. Retrieved from http://www.statcan.gc.ca/pub/89654-x/89-654-x2014003-eng.htm (Accessed 13 September 2018)

[19] Troiano, P. (2003). College Students and Learning Disability: Elements of Self-Style. Journal of College Student Development, 44(3), 404-419. doi: $10.1353 /$ csd.2003.0033

[20] Zheng, C., Gaumer Erickson, A., Kingston, N. M., \& Noonan, P. M. (2014). The relationship among selfdetermination, self-concept, and academic achievement for students with learning disabilities. Journal of Learning Disabilities, 47(5), 462-474.

[21] Boostrom, R. (1994). Learning to pay attention. International Journal of Qualitative Studies in Education,7(1),51-64. doi:10.1080/0951839940070104. 